Available online at www.ktu.edu.gh

International Journal of Technology and Management Research 6 (2021)
International Journal

\title{
An Assessment of Students' Interest in choosing Technical Programmes among First Cycle Institutions in the Eastern Region of Ghana
}

\author{
Akorli Solomon King and Adu Gyamfi Timothy²
}

1,2Koforidua Technical University- Faculty of Built and Natural Environment; Department of Building Technology.

${ }^{1}$ Correspondence: soking1975@yahoo.com

\begin{abstract}
Technical and Vocational Education is imperative when considering the human resource development of a country. The challenges facing Technical and Vocational Education in the Eastern Region is the consistent diminution of students opting to pursue Technical and Vocational courses at the Secondary level of education. The study seeks to assess student's low interest in choosing Technical programme at the Second Cycle Institutions in the Eastern Region of Ghana. The sampling technique used was stratified and simple random sampling. The research was a cross -sectional studies and field questionnaire survey was used to collect information for the study. Data was collected from one thousand, one-hundred and six $(1,106)$ respondents. Data were analyzed using frequency, charts and other relative important Indexes. It was found out that students 'have low interest in technical courses due to societal stigmatization against the programme. The concept of Vocationalization must be re -visited at the Basic levels of the educational system.
\end{abstract}

Keywords: Technical Courses; Second Cycle Institution; Technical education; interest; skills

Citation: Akorli, S. K. and Gyamfi, T. A. (2021). An Assessment of Students' Interest in choosing Technical Programmes among First Cycle Institutions in the Eastern Region of Ghana. International Journal of Technology and Management Researcch. Vol. 6, Issue 1: 1-13.

Received: April 15, 2020

Accepted: March 30, 2021 


\subsection{Introduction}

\subsection{Background}

In the world today, education has assumed a pivotal role in the developmental front of every nation. The role of education in facilitating environmental, economic and societal improvement has long been globally recognized and many nations acknowledging the very essence of education and its numerous impacts on human society (Sherry et al., 2013). The world has resolved to take national policies to employ realistic and efficient instructive techniques for knowledge acquisition, transfer and its consequential applications among members (Sherry et al., 2013).

According to Ali (2015) Technical and Vocational Education (TVE) is imperative when considering the human resource development of a country. Ali (2015) thinks creating skilled human labour force, enhancing industrial productivity and improving the quality of life are definitive output of an effective Technical and Vocational Educational System.

Considering the overwhelming importance of Technical and Vocational Education, Ghana has carved policy initiatives to promote technical education in the country (Ali, 2015). Technical and vocational educational system in Ghana dates back to about a century ago; with government consistently making efforts to refine and employ contemporary teaching methods, thus, harmonizing it with the global educational systems on Technical and Vocational Education (Akyeampong, 2002). The same Author posited that, to place enrollment in TVE in a correct perspective, it is prudent to start with an overview of enrollment in formal education establishments which lay the basis for formal Technical and Vocational Education and Training (TVET) provision in Ghana. The beginning of formal TVET happens after basic education, that is, after the completion of Junior High School. Although significant technical education is captured in the curriculum at the Junior High School level, there is lack of vocational and technical teachers for JHS, this phenomenon has forced authorities to persuade mathematics teachers to enroll for two-week orientation courses for them to able to teach pre-vocational and pre-technical skills (Akyeampong, 2005).

In the Public school system, the main TVET institutions are the Technical Training Institutes (TTIs), the National Vocational Training Institute (NVTI) centers, the Polytechnics and Technical Universities. Most at times the terms Technical Education and Vocational Training are often used synonymously (Akyeampong, 2005). However, as per present practice, a subtle difference exists when used in academia. According to Albert (2002) the term Technical Education refers to post-secondary courses or subjects of study and practical training which are geared toward preparation of technicians to perform supervisory roles in industry. The term Vocational Training is restricted to lower level education and training for the population of skilled or semi-skilled human workforce in various trades and it does not enhance their level with respect to general education.

Nsiah-Gyabaah (2009) believed that when TVET and Competency-Based Training (CBT) education are accepted and implemented very well it will help to reduce the high level of extensive poverty and deprivation because science and technology can solve so many problems in all fields of life. 
The aim of the study is to assess JHS students' interest in choosing Technical Programme at the Second Cycle Institution in the Eastern Region of Ghana.in achieving this, the following specific objectives were:

To find out Students' attitude towards Technical programme at the Second Cycle Institution in the Eastern Region

$>$ To ascertain the factors considered by teachers at the JHS in selecting SHS programmes for students

$>$ To identify factors that students consider in selecting programme of study at SHS

\subsection{History of Education in Ghana}

According to Oti-Agyen (2007) Ghanaian societies have their own distinctive ways of educating its members; though some societies did not develop the art of literacy, education still went on in those societies and such education was described as practical and pragmatic. Indigenous Ghanaian education was highly informal which combined not only physical with character training but also manual with intellectual training. One aspect of Traditional Education that was central to indigenous was Vocational Training. One important point about Vocational Training among the pre - colonial Ghanaians, according to Oti-Agyen (2007) it makes a person economically independent and earned a decent living, these people are well-respected in African society, therefore every effort was made to equip the people with viable economic skills.

The introduction of Western formal education in Ghana was closely tied to the coming of the European merchants from the middle of the fifteenth - century. The idea of the European merchant to educate the indigenous to help them in trading was carried out by the Christian missionaries as well. One important educational philosophy that help vocationalization in Ghana was that of Wesleyan mission. They gave technical and vocational education a boost in 1880 s when Rev. Kemp re-organised schools of the mission at cape coast and Accra. He includes the study of technical and vocational subjects in the schools. In addition, a technical boarding school was established at Cape Coast to train pupils in handicraft (Oti-Agyen, 2007).

Since the attainment of Ghana's independence, every government have confirmed their acknowledgement of the importance of education to national development, by following policies aimed at making education available to all and appropriate to the social, industrial and technological development of the country through educational reform like the introduced of Junior Secondary School concept source.

\subsection{Vocational and Technical Education in Ghana}

The concept of Vocational and Technical Education was conceived in 1967 when a tripartite National Manpower Board comprising representative of the government, employers and workers was established in order to plan effective development and utilization of human resource (Adu - Gyamfi, et al., 2016). 
According to Essel et al., (2014) after independence in 1957, the government envisioned the vital need for the strengthening of the Vocational and Technical Training for the manpower development of the country. After a comprehensive study of the country's manpower needs and the existing facilities for skill training, national vocational training programme was established. According to Adu - Gyamfi, et al. (2016) an Act of Parliament 351 of $12^{\text {th }}$ January 1970 was passed to legalize the establishment of the Vocational and Technical Institutes (Adu - Gyamfi, al et., 2016). Budu-Smith (2005) believed that the benefit of Technical and Vocational Education and Training (TVET) in nation building cannot be over stressed. According to Budu-Smith (2005) technical and vocational education is a chief agent for industrial development as well as for social progress of any country. It was emphasized that without skilled technical manpower, national growth would virtually grind to a standstill.

Ansah and Kissi (2013) believed that Technical and Vocational Education and Training (TVET), is devastating both in terms of fulfilling human safety and as an investment with very high returns.

The traditional and universally recognized purpose of vocational education in general has been the provision of occupational skills for employment according to Baffour-Awuah and Thompson (2012).

Baiden (1996) has seen that Vocationalization policy in Ghana has had similar purposes as others. He mentioned some of the purposes of technical, vocational education (TVE) in Ghana as: to expose pupils at the Basic Education level to a variety of practical activities in the vocational field in order to make them familiar with, and rouse their interest in, vocational subjects; To prepare students who have finished Basic Education with those professional skills that will enable them to enter into gainful employment in industry and commerce; to equip students with the relevant productive and entrepreneurial skills that will prepare them for self-employment etc.

According to Nsiah-Gyabaah (2009), 'there has never really been any argument over the link between education and development because education helps to build national capacity to apply science and technology to social and economic problems. Education is a fundamental human right and it is necessary for socio-economic development of society. It is a means to the fulfilment of an individual and the transfer of values from one generation to the other.

According to Ansah and Kissi (2013), to help a country attained economic prosperity, "it is the people with requisite scientific and technological education and technical skills that can create wealth towards that achievement". In the context of this realization, TVET has been recognized as constituting a vital segment of Ghana's educational system and human resource development initiative (Ansah and Kissi, 2013)

\subsection{Procedure in Choosing Programme of Study at SHS Level}

According to Gati and Saka (2001 career choice is important during adolescence, when individuals naturally begin to discover their abilities, values, interests, and opportunities in preparation for career exploration. For Hiebert (1993) "choosing a career is perhaps second only to choose of mate in terms of the pervasiveness of the impact on one's life". 
According to Namale (2012), every student at the threshold of life has to find a satisfactory answer to an important question ,what shall I do in life? "e

In order for the JHS pupils to fulfill their academic and career dream, provisions have been made for them to select the prefer programme of study for SHS before their BECE.

The Ministry of Education in conjunction with Ghana Education Service has grouped all second cycle into categories. Public Second Cycle Institutions were categorized as A, B, C and D. Category E comprises all Second Cycle Schools that offer Technical or Vocational programmes and Private Schools - Senior High and Technical and Vocational institutions are in Category E and G respectively. The students were allowed to choose five different schools that they will like to be placed (Ghana Education Service, 2020).

Parents are always invited by school authorities and selection procedures explained to them. Pupil have to choose from category A to E. Pupils are advice to choose one school from category A, two from category B, three from category C and one from category $\mathrm{D}$ and $\mathrm{E}$. Student who desire to pursue purely Technical programmes may select $1^{\text {st }}$ to $4^{\text {th }}$ schools from Technical or Vocational category and can still select the $5^{\text {th }}$ from category D (Ghana Education Service, 2020). According Salifu, (2000) every year, junior high school students are faced with the problem of selecting a programme for study. According to the same Author most researchers argue that the selection process typically involves considering many factors such as the career interests of students prospects of employment and job security, intellectual ability and Interest (Olayinka 1993).

Consequently, in helping to select a career for the student, parents are often attracted by the loftiness or lucrativeness of the profession, irrespective of the fact whether the student is fitted for the career or not. They think that „success is entirely confined to the high peaks, forgetting that the lovely violet which modestly fulfill its mission by shedding its fragrance all around it, is as worthy of praise as the mighty oak under whose shadow it blooms and dies ${ }^{\mathrm{ee}}$. Nothing can be harmful to a person than an ambition which over-reaches itself. A person with a career in which he is a misfit goes through life devoid of physical vitality or intellectual vivacity needed for a fulfill life (Namale 2012). Based on Namale's statement, selection of a wrong career leads to discontent or dissatisfaction and final failure, since the career follows is not just a means of earning a livelihood but also a means of life.

\subsection{Methodology}

The study was conducted through field surveys to assess students' low interest in choosing Technical programme among First Cycle Institution in the Eastern Region of Ghana. The main instrument used for data collection was structured questionnaire survey made up of opened and closed-ended questions. The questionnaire was administered to the Regional Director of Education, Municipal and District Directors of Education, Heads and Teachers and Students at the Junior High Schools. 
Stratified random sampling was used to select the Municipals or Districts by stratifying the twenty - six (26) districts into five (5) stratum. Five (5) Districts were selected from the stratum; one District from each stratum. Random sampling was used to select four (4) schools from each Districts (Duodu and Asamoah - Gyimah, 2007)

The information required was solicited from Regional Director of Education, five (5) Municipal and District Directors of Education, hundred (100) Heads and Teachers from selected JHS and one - thousand (1000) Students at the Junior High Schools were selected to form the sample size for this research.

A quantitative approach to data analysis was employed. Statistical Product and service solution (IBMSPPSS Version 25) was used to analyze the data by means of frequencies, charts and Relative Important Index.

\subsection{Results}

In all, one thousand, one-hundred and six $(1,106)$ questionnaires were distributed and all were retrieved since the researchers were there before the respondents finished their responses, indicating 100\% response rate. The Eastern Region has a total of one - hundred and fourteen (114) Second Cycle's Schools. Figure 1 shows the strength of each programme offered by the Second Cycles in the Region and the number of schools that offers a particular programme. In total there are seven courses offered by the one - hundred and fourteen (114) Second Cycle Institutions as received from Directors of Education.

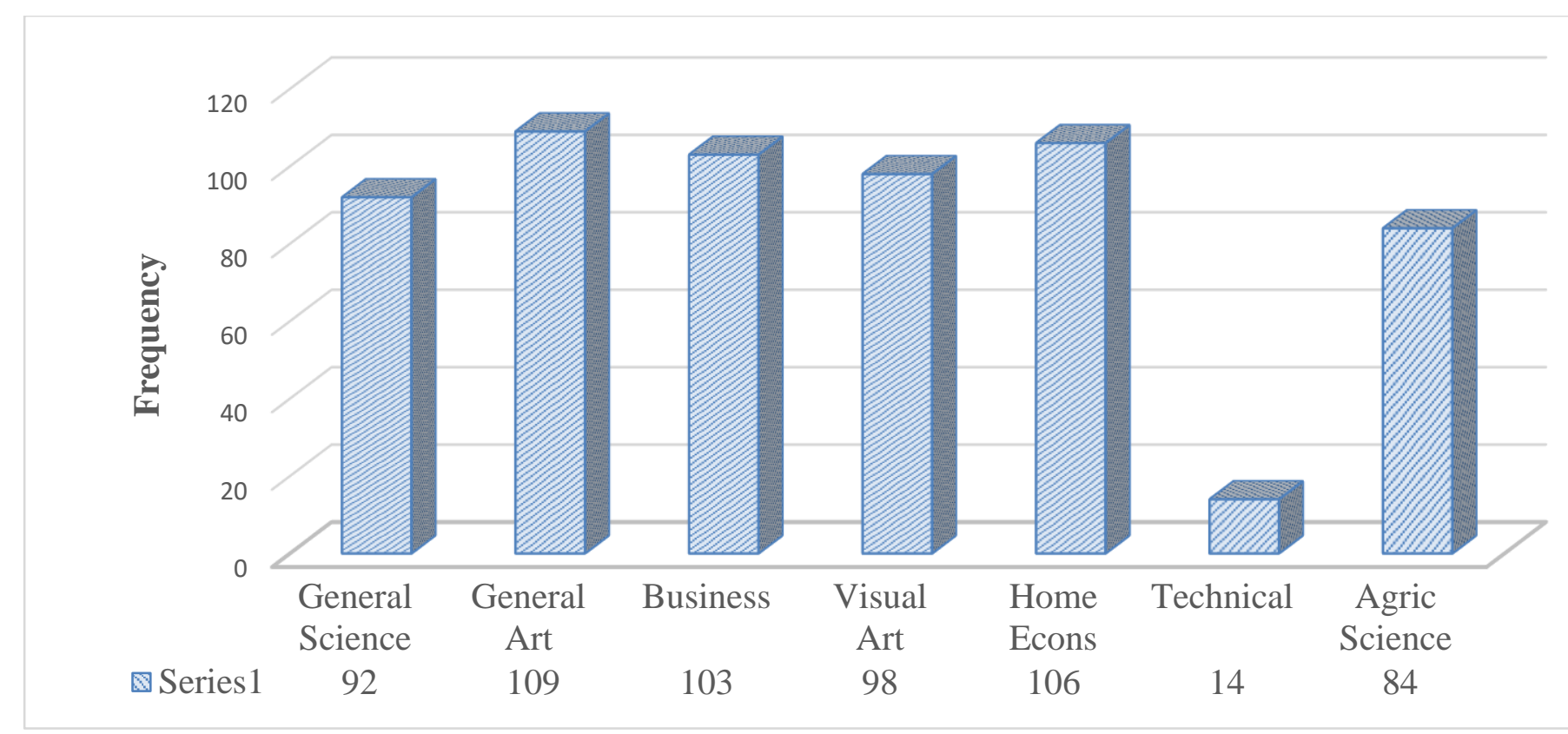

Figure 1 Number of schools offering a particular course 


\section{1 Student's Responses}

\subsubsection{Prefer Course at the Second Cycle Schools}

The prefer course students want to pursue at the Second Cycle Institution after their BECE has been illustrated in fig 2 below.

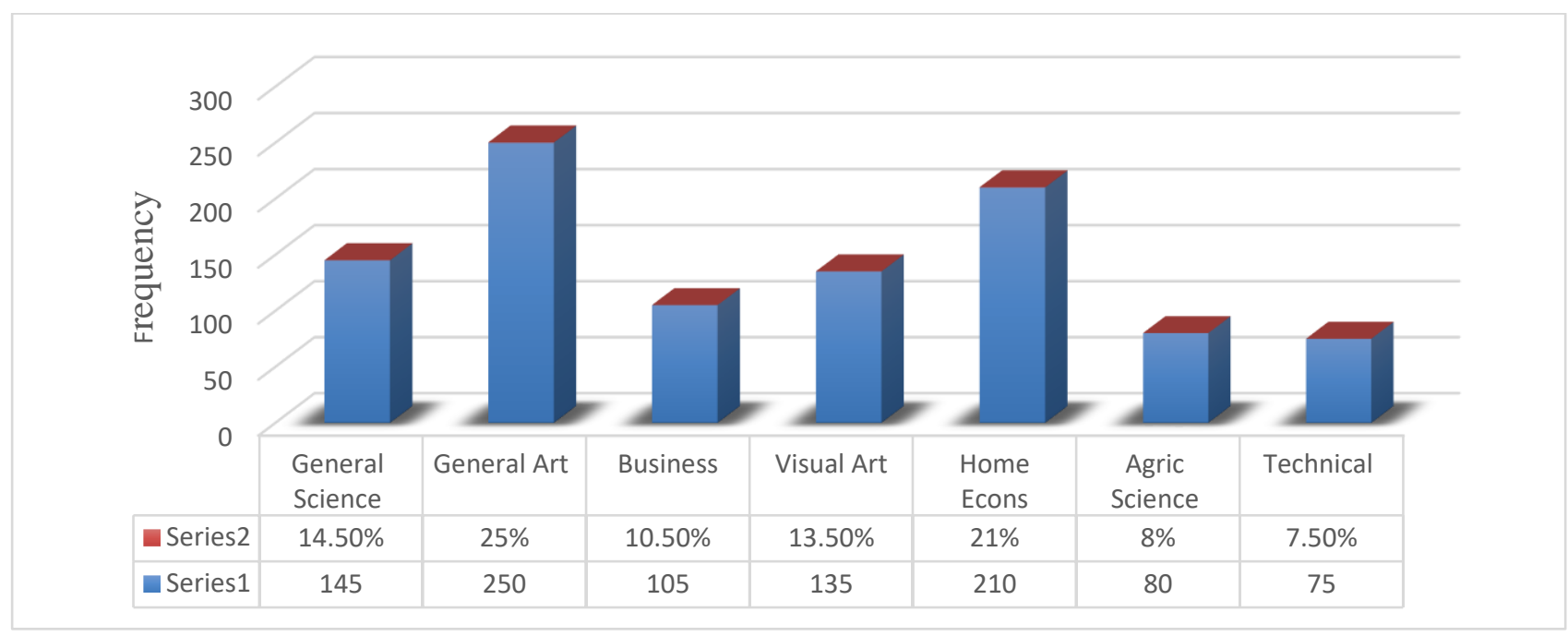

Figure 2 Prefer Course of study at the Second Cycle Schools

The result from Fig 2 shows that out of 1,000 students who answered the questionnaires, 25\% of the students prefer to offer General Arts in the Second Cycle Schools. 21\% of the students prefer to offer Home Economics and 14.5\% prefer to offer General Science. 13.5\% of the Junior High Schools students prefer Visual Arts at the Second Cycle Schools while $10.5 \%$ of the respondents said they prefer Business course. $8 \%$ and $7.5 \%$ out of the $100 \%$ respondents prefer Agriculture course and Technical respectively.

\subsubsection{Students Perception about Technical Course}

The broad purposes of technical, vocational education (TVE) in Ghana are: to expose pupils at the Basic Education level to a range of practical activities in the vocational field in order to make them familiar with, and arouse their interest in vocational subjects. This will give them equal opportunity to choose their future careers in either the technical or general field (Akyeampong, 2005).

These broad purposes were used to test the knowledge of the students about the Technical courses. The table 1 below represents their opinions. 


\begin{tabular}{|c|c|c|c|c|c|c|}
\hline \multirow[t]{2}{*}{ Students Perception } & \multicolumn{2}{|c|}{$\begin{array}{l}\text { Respondent's } \\
\text { judgments }\end{array}$} & \multirow[t]{2}{*}{$\begin{array}{l}\text { Total } \\
\text { Weight }\end{array}$} & \multirow[t]{2}{*}{$\begin{array}{l}\text { Weighted } \\
\text { Mean }\end{array}$} & \multirow{2}{*}{$\begin{array}{l}\text { (RII) } \\
\text { Index }\end{array}$} & \multirow[t]{2}{*}{ Rank } \\
\hline & 1 & 2 & & & & \\
\hline Lack of knowledge of careers in Technical course & 159 & 841 & 1841 & 1.84 & 0.92 & $2^{\text {nd }}$ \\
\hline Technical career is a job for the illiterates & 891 & 109 & 1109 & 1.11 & 0.55 & $7^{\text {th }}$ \\
\hline Technical course as career is for only men & 200 & 800 & 1800 & 1.80 & 0.90 & $5^{\text {th }}$ \\
\hline $\begin{array}{l}\text { Technical courses are becoming more theoretical } \\
\text { than Practical }\end{array}$ & 189 & 811 & 1811 & 1.81 & 0.91 & $4^{\text {th }}$ \\
\hline $\begin{array}{l}\text { Lack of sufficient industries to employ Technical } \\
\text { Students }\end{array}$ & 389 & 611 & 1611 & 1.61 & 0.81 & $6^{\text {th }}$ \\
\hline $\begin{array}{l}\text { Lack of education on the importance of Technical } \\
\text { courses from stake holders }\end{array}$ & 90 & 910 & 1910 & 1.91 & 0.96 & $1^{\text {st }}$ \\
\hline Societal stigmatization on Technical courses & 185 & 815 & 1185 & 1.82 & 0.91 & $3^{\text {rd }}$ \\
\hline
\end{tabular}

Note: Agree $(A G)(L S=2$ and Disagree $(D A G)(L S=1)$ (Note: $L S=$ Likert Scale)

The responses from the students in Table 2 revealed the following as the reasons for their low interest in choosing Technical courses at the second cycle schools: Lack of education on the importance of Technical courses from stake holders was rank first with RII of 0.96. Lack of knowledge of careers in Technical course was rank $2^{\text {nd }}$ with RII of 0.92. Societal stigmatization on Technical courses was rank $3^{\text {rd }}$ reasons of their low interest in choosing Technical courses at the second cycles with RII of 0.91 . Technical courses are becoming more theoretical than Practical was rank $4^{\text {th }}$. Students see Technical course as career for only men and Lack of sufficient industries to employ Technical Students.

\subsection{Responses from Heads and Teachers}

\subsubsection{Number of Students who offers Pre - Technical skill and Home Economic}

Pre - Technical Skill and Home Economics are the main division of the Basic Design and Technology (BDT) subject at the Junior High School. Students are allowed to choose one of them for study. Fig 3 shows the number of students who prefer to study Pre - Technical Skill and Home Economics. 


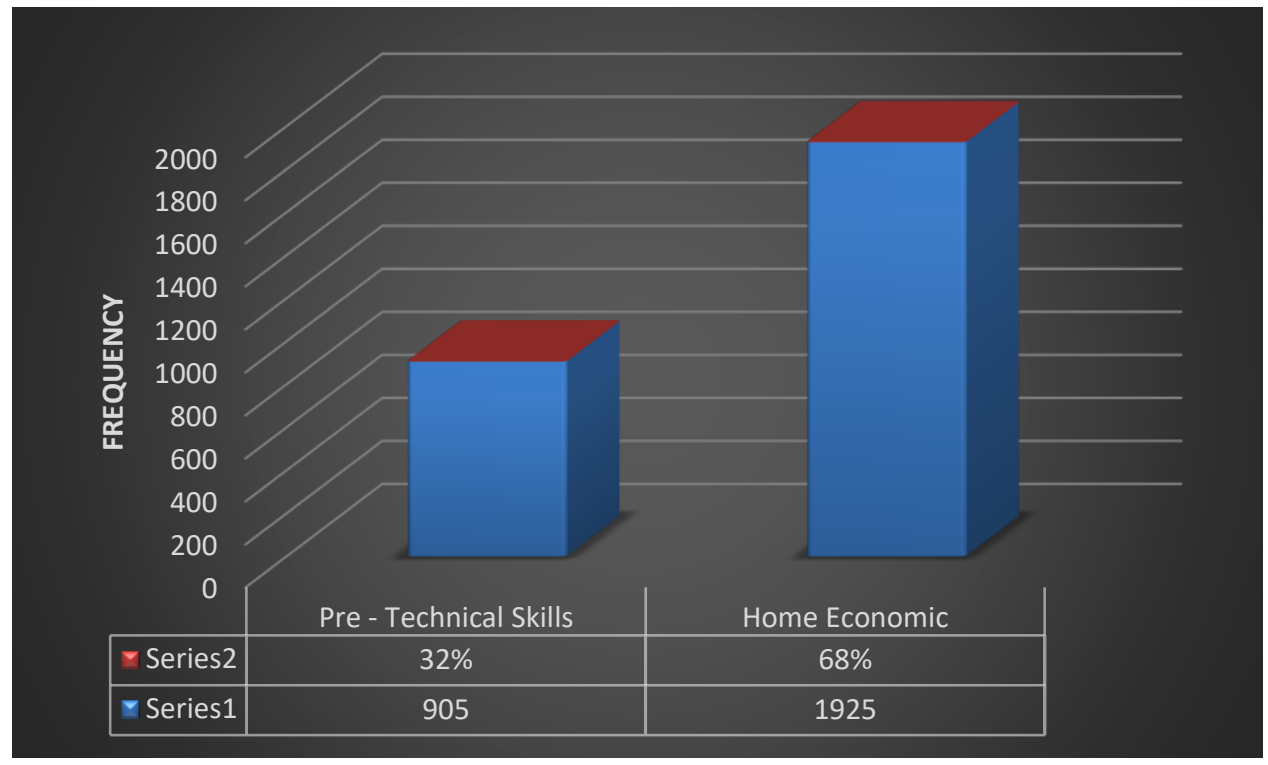

Figure 3 preference of pre - technical skill and home economic

The data presented in Fig 3 from the twenty JHS visited, 32\% were students offering Pre - Technical Skill while 68\% choose to offer Home Economics.

\subsubsection{Selecting Programmes of study at the Second Cycle Schools}

Teachers are supposed to guide student to select courses to pursue at the second cycle level of their education. Table 2 revealed the factors teachers consider when choosing courses of study for students at the Second Cycle institutions.

Table 2: factors to consider in selecting courses for students

\begin{tabular}{l|l|l}
\hline Elements & Response & Rank \\
\hline Students interest & 95 & $1^{\text {st }}$ \\
Students' academic performance & 92 & $2^{\text {nd }}$ \\
Parent / Guardian interest & 90 & $5^{\text {th }}$ \\
Teachers interest & 8 & $6^{\text {th }}$ \\
Institutions within your catchment area & 88 & $4^{\text {th }}$ \\
Carrier opportunity in offering a particular course & 80 & $3^{\text {rd }}$ \\
Based on consensus between Teachers, Parents and students & & $7^{\text {th }}$ \\
\hline
\end{tabular}

From Table 2, factors considered include; Students interest, Students' academic performance, Institutions within your catchment area, Carrier opportunity in offering a particular course and Parent / Guardian interest. Factors not necessary considered are Teachers interest and consensus between Teachers, Parents and students.

\subsection{Discussions and Conclusions}

\subsection{Result Discussions}

The findings from Figure 1 shown that the student's low interest in offering Technical courses at the second cycles institutions was based on the low interest from the educational authorities to introduces technical courses at the second cycles institutions. It is clear that out of one- hundred and fourteen (114) second cycle institution within the Eastern Region, only Fourteen (14) schools are offering Technical programme. Even Sherry et al. (2013) report from Ministry of Education Sector Performance Report that the total number of technical institutes (TI) available in Ghana is woefully 
inadequate and as at 2010, statistics by Ministry of education indicate that there are about twenty-one (21) technical institutes (TI) in the country. 109 schools offer General Arts programme and 106 runs Home Economics programme. A result from Fig 2 has revealed the fact about the low interest of pupils at JHS in pursuing technical courses at the second cycles. Out of 1,000 students, only 75 students would like to pursue Technical courses at the second cycle institutions. This result confirmed the earlier result when only fourteen (14) second cycles in the region are running Technical programme. The finding agreed with Akyeampong (2005) who found out that the number of students enrolled in the technical programme tends to be lower, resulting in smaller class sizes compared to science.

The basic idea and direction of Ghana's vision 2020 plan is to reform all Technical and Vocational Education system to make it more open to the national goals and ambitions as well as local and global demands. It is believed that an improved TVET system will promote manufacturing, construction technology, agro-based industry and commerce (Ansah and Kissi, 2013). The attainment of this vision is in danger since from the basic, pupils are not interested in both Technical and Agriculture courses. Out of 1,000 only 155 students prefer the two courses and a large number of 250 prefer General Arts programme. This also tell the reason why 109 schools out of 114 are running General Arts programme. It is clear from the result that students are sometime affected by programme or course proximity. If more schools are offering Technical programmes or courses the students will see its relevance and will like to pursue it. The higher the programme is run in the region by the school the higher the students' interest in pursuing that programme. General Arts was the highest course offered by the second cycles and record the highest student's interest. Home Economics was the second highest course offered by the second cycles and also have the second highest interest.

Result from Table 1 shows that students has ranked lack of education on the importance of persuading Technical courses from stake holders as the highest factor why they don't choose technical course at the second cycle schools with the highest RII of 0.96. The first reason was followed closed by lack of career knowledge in Technical course with weighted means of 1.84 and RII of 0.92 as the second highest reason. This revelation is true because since students do not receive education on technical courses surely, they will not also know career opportunities of persuading the course. The third reasons why students do not like selecting technical course at the second cycle was societal stigmatization against the courses with RII of 0.91. It is believed that most people in society look down upon students persuading technical courses or those enrolled at technical and vocational institutions. This disrespect to TVE in recent time has destroyed the interest of pupils from persuading TVE, un like in the time of indigenous educational system. Also, students are not feeling the practical part of Technical and vocational courses at the JHS and this is one of the reasons why their interest has gone cool. At the JHS it now difficult to see all the equipment meant for practical demonstration at almost all the JHS since the introduction of the JHS concept in 1987 not existing. Another pressing factor that reduces students' choice of TVE from the result is that students see Technical course as career for only men. 
The result from the schools visited represented in Fig 3 also shows that pupils are more interested in-Home Economics course than that of Technical course. In second year, students were asked to choose either Pre - Technical or Home Economics from BDT. The record gave 32\% for Pre -Technical and 68\% for Home Economics. This result shows how students' interest are low from the very basic. The Structure and Ministries in Charge of Various TVET Institutions in Ghana under Ministry of Education, Youth and Sports provide the means for the pupils at the JHS to acquire general education and basic technical skills (Nsiah-Gyabaah, 2009) as cited in (Ansah and Kissi, 2013)

Before JHS graduates get to the second cycles institutions they need to select courses of interest. The process is always directed and supervised by their teachers. The research wanted to know the factors the teachers do consider when they are selecting courses for their students. Results presented in Table 2 shows that the teachers depend mostly on the interest of the students to choose courses for them. This phenomenon can lead to students choosing courses not necessary based on their future ambition but my sister or my friend is persuading that, or I think a lot of people are persuading it. Peer pressure can take over reality. Their next factor they do consider is the students' academic performance. The only difference in subject offered is the Pre-technical and Home Economics. If the academic performance will depend on these two subjects, then majority will not go in for Technical also those students who find certain topics of Pre- technical difficult will not be motivated to continue the course. If the third factor is the choice of the Parent or Guardian, then it can also create some few problems since those parents or guardians who illiterates may try to seek advice from some unqualified persons who they will try to impose on the students and the teachers. Proximity of institutions since some students do not want to leave far away from their native town and consideration of carrier opportunity in offering a particular course are other factors considered respectively. Teachers interest per the result was not considered and amazing, consensus between Teachers, Parents and students was not also used to select courses for the students. There is a saying that two heads are better than one, but this collaboration rather was not considered.

\subsection{Conclusions}

Albert (2002) said, to put enrollment in technical and vocational education in a good viewpoint, it is prudent to begin with an overview of enrollment in formal education institutions which lay the foundation for formal TVET delivery in Ghana.

It was noted that upon all nice structure provided by ministry of education to see the JHS pupils acquiring technical skills for onwards development. This structure will not see the light of the day since students' interests are going down day-by-day in technical courses due to lack of education on the importance of persuading Technical courses from stakeholders. There is no TVE Guidance and counselling unit established in the schools or District to be doing constant education for the pupils. The content of the combination of Technical Skills, Technical Drawing, Life Skills and Vocational Skills to form BDT which include Pre- Technical Skills and Home Economics; has limited the skills 
acquisition of the pupils from the basic. And the students' interest has been seriously affected by this limitation of the BDT content. There is the need for the Council for Technical and Vocational Education and Training (COTVET) which was established by an Act of parliament to be responsible for formulating policies to improve the quality, relevance and perception of technical and vocational education and training across Ghana (OECD, 2008) review the responsibilities to see which era is best. Since the perception of the students about the technical courses have been affected there the need for review.

One of the major problems identify is the lack of authorities to introduce Technical programme or courses at the second cycle institutions and the limited technical and vocational institutions in the country. Teachers need to seat with students and their parent to discuss course selection so that students shouldn't study for study's sake. The result shows that Government's recognition of TVET as a means of developing the technical and skilled human resources needs for rapid economic and industrial growth and for realizing the Ghana vision 2020 plan will not be achieved.

\section{References}

Adu-Gyamfi, S., Wilhemina J. D. and Adinkrah A. A. (2016). Educational Reforms in Ghana: Past and Present. Journal of Education and Human Development September 2016, Vol. 5, No. 3, pp. 158-172 ISSN: 2334-296X

Ali T. R. (2015). Relevance of Vocational and Technical Education to Ghana's Socio-Economic

Development. Retrieved January, 2020. Website:https://www.modernghana.com/news/609114/relevance-of-vocational-andtechnical-education.html

Akyeampong, A. K. (2005). Vocationalisation of Secondary Education in Ghana. UNESCO-

UNEVOC Book Series Technical and Vocational Education and Training: Issues, Concerns and Prospects, 149-225. doi:10.1007/1-4020-3034-7_5

Akyeampong, A. K. (2002). Vocationalization of Secondary Education in Ghana Regional Vocational Skills

Development Review. Human Development Africa Region World Bank. Retrieved: December 23,

2019. Website: http://www.siteresources.worldbank.org/.../20295552/VETGhana.pdf

Ansah S.K. and Kissi E. (2013). Technical and Vocational Education and Training in Ghana: A Tool for

Skill Acquisition and Industrial Development.Journal of Education and Practice. Vol.4, No.16. ISSN 2222-1735 (Paper) ISSN 2222-288X

Anonymous (2012). Background History of Education in Ghana. Retrieved: December 23, 2019. Website:

http:/ /www.politicalpola.wetpaint.com/.../history+of+education+in+ghana

Baffour-Awuah, D. and Thompson, S. (2012). A holistic approach to technical and vocational skills development (TVSD) policy and governance reform: The Case of Ghana. Working Document for, ADEA Triennale.

Baiden, F. A. (1996). Technical and vocational education in Ghana. In the development of technical and vocational education in Africa: Case studies from selected countries (pp. 81 - 122). Dakar, Senegal: UNESCO

Budu-Smith, J. (2005). The Need for Polytechnics to Assert and Create a Niche for Themselves among Tertiary Institutions in Human Resource Development: Journal of Polytechnics in Ghana Volume 1, No.1

Duodu, F. \& Asamoah - Gyimah, K. (2007). Introduction to Research Methods in Education. Ghana: Institutes for Educational Development and Extension (UEW)

Essel, O.Q., Agyarkoh, E., Sumaila, M.S. and Yankson, P.D., 2014. TVET stigmatization in developing countries: reality or fallacy. European Journal of Training and Development Studies, 1(1), pp.27-42.

Gati, I., \& Saka, N. (2001). High School Students' Career-Related Decision-Making Difficulties. Journal of Counseling \& Development, 79(3), 331-340. doi:10.1002/j.1556-6676. 2001.tb01978.x

GES (2020). Guideline for selection of school for 2020 placement. Accra Ghana: Ministry of Education. Hiebert, B. (1993). Career education: A time for infusion. Guidance and Counselling, 8(3), 5- 10

Namale, M. (2012). Guidance and Counseling in Education. Accra Ghana: Rich blank Publication. 
Nsiah-Gyabaah, K. (2009) The Missing Ingredients in Technical and Vocational Education in Meeting Needs of Society and Promoting Socio-Economic Development in Ghana; Journal of Polytechnics in Ghana; Volume 3, No. 3

Olayinka, M. S. (1993). Guidance and counseling in Nigeria schools. Lagos: Literamed Publications Ltd

Oti-Agyen, P. (2007). The development of Education in Ghana. Kumasi. Hannoh Press

Salifu, A. F. (2000). Factors influencing students option for the bachelor of education programme in the University of Cape Coast. Unpublished master's thesis, University of Cape, Coast Cape Coast.

Sherry K. A. and Yesuenyeagbe A.K. F. (2013). Challenges Facing Technical and Vocational Education in Ghana. International Journal of Scientific \& Technology Research Volume 2, Issue 6, June 2013: Issn 2277-8616 